\title{
Optimizing the profits and enhancing productivity of rice through mechanization
}

\author{
ATUL R. DANGE, BIRBAL SAHU, R.K. NAIK AND DEVCHAND SALAM
}

Received : 03.04.2017; Revised : 21.07.2017; Accepted : 05.08.2017

See end of the Paper for authors' affiliation

Correspondence to :

BIRBAL SAHU

Krishi Vigyan Kendra (IGKVV), KANKER (C.G.) INDIA Email : kvkkanker@gmail. com
- ABSTRACT : Paddy is the principal crop and the central plains of Chhattisgarh are known as rice bowl of central India. It is a labour intensive crop and requires about 800 to 900 labour-hours for cultivating one hectare of land. Of different field operations, seeding through seed drills, transplanting, weeding through mechanical weeder and harvesting together consume major labour force and if these are managed timely and efficiently by the farmers, could earns good profit. An experiment was conducted at Krishi Vigyan Kendra, Kanker to assess the performance of machines used in cultivation of rice. Different machines were evaluated for particular operations. For mechanical transplanting a self propelled rice planter and paddy seeding under wet conditions an eight row paddy drum seeder were used. For weeding manually operated weeder and self propelled paddy reaper for harvesting of paddy were also evaluated. An eight row self propelled paddy transplanter was found to be very effective for timely transplanting in a large area. Its average field capacity was $0.192 \mathrm{ha} / \mathrm{hr}$ and cost of transplanting almost 61 per cent less compared to manual transplanting. Use of manually operated 8 row drum seeder tested was most effective for line sowing of sprouted paddy in puddled condition. It reduces the cost of cultivation by saving 58 per cent seed compared to farmers practice. On the other hand, weed efficiency was found maximum 83.87 per cent with Ambika paddy weeder. It was observed that the average cost of mechanical transplanting with an eight row self propelled rice transplanter $74.71 \%$, mechanical weeding with ambica paddy weeder was 51.15 per cent and mechanical harvesting with a self propelled vertical conveyer reaper was 59.76 per cent less as compared to manual transplanting, weeding and harvesting operations, respectively.

- KEY WORDS : Mechanization, Transplanter, Drum seeder, Productivity

- HOW TO CITE THIS PAPER : Dange, Atul R., Sahu, Birbal, Naik, R.K. and Salam, Devchand (2017). Optimizing the profits and enhancing productivity of rice through mechanization. Internat. J. Agric. Engg., 10(2) : 331-336, DOI: 10.15740/HAS/IJAE/10.2/331-336. 